\title{
Implementation of Competency Based Human Resource and Knowledge Management to Organizational Culture and Implication to Organizational Performance
}

\author{
Sri Suwarsi \\ Doctoral Student, Economic and Business Faculty of Padjadjaran University, \\ Bandung, Indonesia \\ Lecturer of Bandung Islamic University, Bandung, Indonesia \\ Email: srisuwarsi@yahoo.com \\ Ernie Tisnawati Sule \\ Economic and Business Faculty of Padjadjaran University, \\ Bandung, Indonesia \\ Email: ernie.tisnawati@fe.unpad.ac.id
}

\section{Hilmiana}

Economic and Business Faculty of Padjadjaran University, Bandung, Indonesia Email: hilmiana@fe.unpad.ac.id

\section{Arief Helmi}

Economic and Business Faculty of Padjadjaran University, Bandung, Indonesia Email: Ariefhelmi17@yahoo.com

Doi:10.5296/ijhrs.v4i3.5987

URL: http://dx.doi.org/10.5296/ijhrs.v4i3.5987

\begin{abstract}
This study aims to analyze the implementation of competency based human resource management, knowledge management, organizational culture, organizational performance, and the influential correlations both partially and simultaneously. The analysis unit of the study conducted in 42 regions in the five state-owned energy sector companies in Indonesia. Therefore, the units of observation in this study were composed of 47 middle managers, 81 line managers and 155 employees and analyzed by using the Structural Equation Model (SEM) based on the model variance with Partial Least Square (PLS). The result showed that the implementations of competency-based human resource management, knowledge management, organizational culture and organizational performance have been achieved well. The simultaneous implementation of competency-based human resource management and knowledge management had a small effect on the performance of the organization and so not significant. The simultaneous implementation of competency-based human resource management and knowledge management had a very large effect on the performance of the
\end{abstract}


organization through the organizational culture.

Keywords: competency-based human resource management, knowledge management, organizational culture, organizational performance, state-owned energy sector company

\section{Research Background}

An organizational performance can be achieved through a variety of factors, where one key factor is human factor. To direct human behavior toward the achievement of the objectives, it is required human resource management system that deliberately developed to support a positive behavior. The system that has been developed was a system of human resource management based on competency.

Competency-based human resource management (CBHRM) is a pattern approach in building of human resource management system that is reliable to utilize the competence of employees as a center. To point expedite the process of human resource management implementation, it is required to be structured and integrated competency-based management. Therefore, the human resource (HR) department needs to raise its role, not only as an administrative expert but also being a strategic partner. In the absence of CBHRM implementation, it needs a alignment to the vision, strategies and key organizational capabilities. If the alignment is realized, there will be a process of internal integration (internal fit) among the individuals, departments, business units, divisions and the organizational goals.

Along with the development of information technology, the company also works to implement the knowledge management to support all company programs. The knowledge management is a strategy used by the organizations to facilitate knowledge workers to transfer the knowledge, which is done systematically to construct, renew, and applying knowledge to achieve the organizational effectiveness.

The successful implementation of competency-based human resource management and knowledge management needs to be supported by an optimal organizational culture. One of indicators of successful CBHRM implementation is acculturation, that the implementation of the system has the competence to guide how to act employees. Similarly, the indicators of successful implementation of knowledge management is the transformation of knowledge to take place continuously and eventually into the culture and how the members of the organization.

The state-owned energy sector company organizational performance issues the energy sector viewed from a financial perspective in the 5 (five) years (2005-2010), occur up and down, even in 2005, 2007, and 2008 the companies suffered higher losses. The company performance, according the perspective of the customer, based on the data as 13\% YLKI community power users, was not satisfied to the PLN electricity service, and this percentage was much higher compared to neighboring countries, like Malaysia as only 3\% and Hong Kong that no electrical complaint.

By looking at the prospects, challenges and ongoing issues in line with the dynamics, the state-owned energy sector companies in Indonesia need to analyze the role of the department of human resource in order to contribute to optimal attraction and retain people with the skills, 
knowledge and competency needed by the organizations. In addition, its implementation requires a favorable climate for the development of knowledge, maintenance of knowledge, transfer of knowledge, application of knowledge, leadership support and technology to create a climate of innovation. Thus, the superior performance of human resources can be achieved to support and improve the image of the state-owned energy sector companies in the images of stakeholders.

\section{Identify the Problem}

The phenomenon of the state-owned energy sector company organizational performance was not optimal in the four aspects, i.e. financial, customer, internal business process, innovation and learning aspects. The management of human resources and knowledge was not optimal to produce a professional human resource to the competency supported by appropriate core values to develop the companies.

There were many factors to affect the performance of the companies. However, there was a presumption that the application of competency-based human resource management and knowledge management performance to the companies was influenced by the strength or weakness to guide the implementation of the organization's culture and way of working or acting member of the organizations.

The key to the successful implementation of the organization's culture lies in the human aspect determine the future of company through the human intellectual and actions. By a strong corporate culture, every member of the organization has the values, attitudes and behaviors that support the quality work.

Based on the identification and background of the problem that has been stated previously, the formulations of the problem in this study were as follows:

1. How the implementation of competency-based human resource management (CBHRM), knowledge management, organizational culture, and organizational performance in the state-owned energy sector companies in Indonesia.

2. How much the influence of the competency-based human resource management and knowledge management implementations, both partially and simultaneously to the culture of the organizations in the state-owned energy sector companies in Indonesia.

3. How much the influence of the competency-based human resource management and knowledge management implementations both simultaneously and partially on the organizational performance in the state-owned energy sector companies in Indonesia.

4. How big the influence of organizational culture on organizational performance in the state-owned energy sector companies in Indonesia.

5. How much the influence of the competency-based human resource management and knowledge management implementations simultaneously on the organizational performance through the organizational culture in the state-owned energy sector companies in Indonesia.

\section{Literature Review}

The implementation of the competency-based human resource management application in the recruitment process, training, performance assessment, development and succession planning 
are taking into account the various requirements in order to be successful in their competency implementation.

Based on the various theories and research, the dimensions used to measure the implementation of the competency-based human resource management in this study were as follows:

(i) Alignment, the competence has been associated with vision, strategy and key organizational capability. This was consistent with the results of the study U.S. Office of Personal Management (1991:1); Schoonover (2002); Dubois (2004); Enas Hamzi (2011); and Suzanne Simpson and Lorraine McKay (2008);

(ii) Integration, the competence has been applied in all HR functions comprehensively and systematically. This was in line with the opinion of Schoonover (2002); Mohammad Hijazeh, Enas Hamzi (2011); Suzanne Samson (2008); Stephen Josephat (2011); David D Dubois (2000); Mubarrak Sigit (2012) and Kandula R Srivivas (2013);

(iii) Distribution, the ongoing competency standards were actively communicated and used by all employees. This was in line with the opinion of Schoonover (2002);

(iv) Self-Directed Application, the successful competence was simple and easily understood by all employees without always assisted by an HRD team, as mentioned by Schoonover (2002);

(v) Acculturation, the implementation of competence would be successful if it could be a guide how to act all employees, in line of Schoonover (2002).

The implementation of knowledge management is a process for creating, documenting, sharing, and updating on the knowledge in the organization that supported by the company's main pillars which include leadership and technology. Thus, it becomes a culture of knowledge sharing in the company (Nonaka: 1995; Alavi \& Leidner: 2001, Newman \& Brian: 2009).

Based on the various above theories and researches, the dimensions of which were used to measure the implementation of knowledge management in this research were as follows:

(i) Knowledge creation, which was an activity associated with the entry of new knowledge into the organization that includes the knowledge development, knowledge discovery and knowledge absorption (Nonaka \& Takauchi: 1995; Horwitch \& Armacost: 2002; Davenport: 1998; Alavi \& Leidner: 2001; Bassi; 1997);

(ii) Knowledge retention, which was an activity associated with the maintenance and storage of knowledge, including knowledge of activities to keep the knowledge remains within the organization (Schultze \& Leidner: 2002; Horwitch \& Armacost: 2002; Bassi; 1997);

(iii) Knowledge transfer, which was an activity that was related to the flow of knowledge from one party to the other party, which includes communication, translation, conversion, filtering, and knowledge translation (Schultze \& Leidner: 2002; Bhatt: 2001; Davenport: 1998; Alavi \& Leidner: 2001; Scarborough: 1999);

(iv) Knowledge utilization, which was an activity associated with the application of knowledge to the organization's business processes (Abell \& Oxbrow: 2001; O'Dell: 2000; Scarborough: 1999); 
(v) Management and leadership suport, namely the support of the leadership and concrete steps to realize the implementation of knowledge management in any business activity (Scarborough \& Carter: 2000; Nonaka: 2009; Alavi \& Leidner: 2001; Kusno Prijono: 2008; Jones: 2002; Davenport: 1998; Chong: 2005; Wong: 2005; and Albers: 2009);

(vi) Corporate entrepreneurship, namely the extent of emerging entrepreneurial culture within the organization in order to create new services (Hibbard: 1997; Jones: 2002; Malhotra: 1998);

(vii) Application of technology, namely the extent of technology play a role in the process of implementation of knowledge transfer was not limited by distance and time (Davenport: 1998; Bassi; 1997; Frappaulo \& Toms: 1997; Nonaka: 2002; and Alavi \& Leidner: 2001).

The organizational culture is a shared meaning system held by the members that could distinguish one another among the organizations (Robbins, 2010). The strong organizational culture tends to support the objectives of company, and vice versa, the weak or negative cultures would hinder or conflict with corporate goals. The organizational culture has a very strategic role in encouraging and enhancing of organizational performance through superior behavioral changes that always want to produce something as the highest quality level.

The measurement of the existence of organizational culture is needed to be done. It aims to find out how strong the organization's members hold values that exist within the organization, to the interests of the measurement of organizational culture that could be made to the members of the organization, or in this case, it was an employee of the companies.

To measure the strength or weakness of the organizational culture in the state of energy sector in Indonesia, in this study, the researchers used the opinions expressed by Robbins (2010), because these values corresponded to the conditions on the object that being studied. According to Robbins (2010), that in order to assess the quality of the organizational culture of company, it could be measured by using the 7 (seven) characteristics include, (i) Innovation and risk-taking; (ii) Attention to detail; (iii) Outcome orientation; (iv) People orientation; (v) Team Orientation; (vi) Aggressiveness; (vii) Stability.

The organizational performance was a view over the whole state of the company over a period of time. The result was affected by the operations of the company in utilizing the owned resources (Veithzal Rival 2009). The balance scorecard is a framework for integrating various sizes derived from the corporate strategy, which is a measure of financial performance driving past and introduce future financial performance, including customer perspective, internal business processes, and learning and growth. It was derived from the corporate strategy explicitly and strictly implemented to the objectives and real measures (Kaplan \& Norton 2000).

Based on the theories and researches on the organization's performance appraisal for the purposes of this study, to measure the performance of the organization in the state-owned energy sector companies in Indonesia, the researchers used the measurement of organizational performance with balanced score card approach which refers to Kaplan \& Noorton (1996), which involved four perspectives, namely; (i) Financial perspective, (ii) Customer perspective (customer perspective); (iii) Internal business process perspective (iv) 
Learning and innovation perspective.

\section{Research Methodology}

In this study, the research method was the explanatory research, which was the study that explained the causal relationships among variables. The variables involved the implementation of competency-based human resources management, knowledge management, organizational culture and organizational performance. The explanatory research referred to the theories or hypotheses that to be tested as the cause of phenomena.

The method of analysis was divided into two parts, descriptive analysis and inferential analysis. The unit of analysis was the organization, namely Branch Offices / Regional Offices of the state-owned energy sector companies in Indonesia, which was spread over 42 regions in the 5 (five) state-owned energy sector companies. The unit of observation had 283 respondents, consisting of 47 middle managers, 81 line managers and 155 employees / staffs to assess how their perceptions of the variables being studied.

This study used the primary and secondary data. The primary data were obtained from the field through the questionnaire to determine the implementation of competency-based human resource management, knowledge management, organizational culture and organizational performance. The secondary data were data that included the real conditions of application of competency-based human resource management, knowledge management, organizational culture, and organizational performance in the 5 (five) state-owned energy sector companies in Indonesia to enrich the descriptive analysis.

The questionnaires used the Graphic Rating Scales in which the respondents were asked to choose each question with an answer on the scale of 1 to 10 and their perceptions of the phenomenon through the survey. The scale used in the questionnaire was the interval scale.

The implemented variables of competency-based human resource management dimension were measured by using 5 items, consisting of 24 questions. The knowledge management implemented variables were measured by using 7 dimensions, consisting of 22 questions. The organizational culture dimensions were measured by using 7 items, consisting of 28 questions, and the organizational performance was measured by using 4 dimensional items, consisting of 27 questions.

Meanwhile, to determine the effect, directly or indirectly, and influence over the simultaneous or partial implementation of competency-based human resource management and knowledge management of organizational culture and its implications for organizational performance, it was analyzed by using the Structural Equation Model (SEM) based on the model variant with Partial Least Square (PLS) with Smart PLS software.

\section{Research Results and Discussion}

\subsection{Descriptive Analysis}

The descriptive hypothesis testing for the implementation of competency-based HR management set the minimum implementation study variables said to be good if the proportion is greater than $6(\mu>6)$. To test the significance of descriptive hypotheses above, steps were: 
a) Calculate the proportion of the study variables used the comparison of the total actual score to the total score of the ideal corrected minimum total score as

$$
p=\frac{T_{\text {Sactual }}-T_{S \min }}{T_{S \max }-T_{S \min }}
$$

b) Value of the test:

$$
Z=\frac{\bar{X}-\mu}{s e(\bar{X})}
$$

i.e. the actual average variable research

$\mathrm{Z}=\mathrm{Z}_{0}$ test table right side, $95 \%=1.645$

The null hypothesis was rejected and the alternative hypothesis was accepted if $\mathrm{Z}>1.645$. This meant that the implementation was achieved with good research variables.

\subsubsection{Analysis of Competency-based Human Resource Management Implementation}

Table 1

\begin{tabular}{|c|c|c|c|}
\hline Dimension & \multicolumn{2}{|c|}{ Total Score } & Category \\
\hline Alignment & \multicolumn{2}{|c|}{7.09} & Appropriate \\
\hline Integration & \multicolumn{2}{|c|}{7.10} & Integrated \\
\hline Distribution & \multicolumn{2}{|c|}{7.23} & High \\
\hline Self Directed Application & \multicolumn{2}{|c|}{7.40} & High \\
\hline \multirow[t]{2}{*}{ Acculturation } & \multicolumn{2}{|c|}{7.05} & Consistency \\
\hline & Number & Average & \multirow{4}{*}{ Good } \\
\hline $\begin{array}{c}\text { The size of the observation } \\
\text { unit }\end{array}$ & 283 & & \\
\hline Item & 24 & & \\
\hline Actual values & 48,839 & 7.17 & \\
\hline
\end{tabular}

Implementation of Competency-Based Human Resource Management

Sources: Data of processing questionnaires in 2014

Based on Table 1 above, the perception of competency-based human resource management in the state-owned energy sector companies in Indonesia was measured by 5 (five) dimensions, with the actual value of 7.717 that classified well.

Table 2

Variable Proportion Test Implementation of Competency-Based Human Resource Management

\begin{tabular}{|c|c|c|c|c|c|}
\hline Variables & $\begin{array}{c}\text { Ideal } \\
\text { Average }\end{array}$ & $\begin{array}{c}\text { Actual } \\
\text { Average }\end{array}$ & STD & Z & Remarks \\
\hline $\begin{array}{c}\text { Implementation of Competency-Based Human } \\
\text { Resource Management }\left(\mathrm{X}_{1}\right)\end{array}$ & 6 & 7.17 & 1.064 & 5.504 & Significant \\
\hline
\end{tabular}


$* *$ Significant at the 0.05 of significance level $\left(\mathrm{Z}_{\text {table }}=1.645\right)$

Source: Data of Analysis Questionnaires, 2014

Table 2 shows the right side average test for the implementing variables of competency-based human resource management. The result was significant on the real level of 5\% and the null hypothesis was rejected. This means that the Competency-based human resource management in the state-owned energy sector companies in Indonesia had been significantly good.

\subsubsection{The Analysis of Knowledge Management Implementation}

Table 3

Implementation of Knowledge Management

\begin{tabular}{|c|c|c|c|}
\hline Dimension & \multicolumn{2}{|c|}{ Total Score } & Category \\
\hline Knowledge Creation & \multicolumn{2}{|c|}{6.92} & High enough \\
\hline Knowledge Retention & \multicolumn{2}{|c|}{6.93} & quite conducive \\
\hline Knowledge Transfer & \multicolumn{2}{|c|}{6.96} & high enough \\
\hline Knowledge Utilization & \multicolumn{2}{|c|}{6.90} & quite capable \\
\hline $\begin{array}{l}\text { Management and } \\
\text { Leadership Suport }\end{array}$ & \multicolumn{2}{|c|}{7.25} & High \\
\hline $\begin{array}{c}\text { Corporate } \\
\text { Entrepreneurship }\end{array}$ & \multicolumn{2}{|c|}{7.15} & High \\
\hline Application Technology & \multicolumn{2}{|c|}{7.16} & High \\
\hline & Number & Average & \multirow{4}{*}{ Good } \\
\hline The sample size & 283 & & \\
\hline Item & 22 & & \\
\hline Actual Values & 43,783 & 7.04 & \\
\hline
\end{tabular}

Sources: Data of processing questionnaires in 2014

Based on Table 3 above, the thorough perceptions regarding knowledge management implementation in the state-owned energy sector companies were measured by 7 (seven) dimension, with the actual value was 7.04 as classified well.

Table 4

Variable Proportion of Test Knowledge Management

\begin{tabular}{|c|c|c|c|c|c|}
\hline Variable & $\begin{array}{c}\text { Ideal } \\
\text { Average }\end{array}$ & $\begin{array}{c}\text { Actual } \\
\text { Average }\end{array}$ & STD & $\mathrm{Z}$ & Remarks \\
\hline Knowledge Management $\left(\mathrm{X}_{2}\right)$ & 6 & 7,04 & 1,159 & 4,480 & Significant \\
\hline
\end{tabular}

** Significant at the 0.05 of significance level $\left(\mathrm{T}_{\text {table }}=1.645\right)$

Source: Data of Analysis Questionnaires, 2014

Table 4 shows the right side average test for the knowledge management variables. The result was significant in the real level of 5\%, so that the null statistical hypothesis was rejected. This 
means that the knowledge management in the state-owned energy sector companies in Indonesia was implemented well.

Based on the 7 (seven) dimensions, there were 4 (four) dimensions that enough category, which consisted of knowledge creation, knowledge retention, knowledge transfer and knowledge utilization. This means that the knowledge management implementation in the state-owned energy sector companies was assessed as not optimally yet among 4 (four) aspects.

\subsubsection{Analysis of Organizational Culture}

Table 5

Measurement of Organizational Culture

\begin{tabular}{|c|c|c|c|}
\hline Dimension & \multicolumn{2}{|c|}{ Total Score } & Category \\
\hline Innovation and Risk Taking & \multicolumn{2}{|c|}{7.17} & High \\
\hline Attention to detail & \multicolumn{2}{|c|}{7.35} & High \\
\hline Outcome Orientation & \multicolumn{2}{|c|}{7.38} & High \\
\hline People Orientation & \multicolumn{2}{|c|}{7.20} & High \\
\hline Team Orientation & \multicolumn{2}{|c|}{7.30} & High \\
\hline Aggressiveness & \multicolumn{2}{|c|}{7.21} & High \\
\hline \multirow[t]{2}{*}{ Stability } & \multicolumn{2}{|c|}{7.18} & High \\
\hline & Number & Average & \multirow{4}{*}{ Strong } \\
\hline The sample size & 283 & & \\
\hline Item & 28 & & \\
\hline Actual Values & 57,506 & 7.26 & \\
\hline
\end{tabular}

Sources: Data of processing questionnaires in 2014

Based on Table 5 above, the actual score among seven dimensions to measure the organizational culture was as 7.26 , as strongly classified.

Table 6

Variable Proportion of Test Research

\begin{tabular}{|c|c|c|c|c|c|}
\hline Variable & Ideal Averages & $\begin{array}{c}\text { Actual } \\
\text { Averages }\end{array}$ & STD & Z & Remarks \\
\hline Organizational Culture (Y) & 6 & 7.26 & 1.097 & 5.731 & Significant \\
\hline
\end{tabular}

** Significant at the 0.05 of significance level $\left(\mathrm{Z}_{\text {table }}=1.645\right)$

Source: Data of analysis questionnaires, 2014

Table 6 shows the right side average test for the organizational culture. The result was significant on the real level of 5\%, and the null hypothesis was rejected. This means that the organizational culture in the state-owned energy sector companies in Indonesia was strongly enough. 


\subsubsection{The Analysis of Organizational Performance}

Table 7

The State-owned Energy Sector Company Organizational Performance in Indonesia

\begin{tabular}{|c|c|c|c|}
\hline Dimension & \multicolumn{2}{|c|}{ Total Score } & Category \\
\hline financial perspective & \multicolumn{2}{|c|}{6.89} & High enough \\
\hline Internal business process perspective & \multicolumn{2}{|c|}{7.27} & High \\
\hline Customer and Stakeholder Perspective & \multicolumn{2}{|c|}{7.31} & High \\
\hline Learning and Growth Perspective & \multicolumn{2}{|c|}{7.32} & High \\
\hline & Number & Average & \multirow{4}{*}{ High } \\
\hline The sample size & 283 & & \\
\hline Item & 27 & & \\
\hline Actual Values & 55,079 & 7.20 & \\
\hline
\end{tabular}

Sources: Data of processing questionnaires in 2014

Table 7 shows the recapitulated result of organizational performance in the state-owned energy sector companies in Indonesia that measured by the balance score cards in the four perspectives with the actual of 7.20 as highly classified. Nevertheless, the financial perspective was enough assessed.

Table 8

Variable Proportion of Test Research

\begin{tabular}{|c|c|c|c|c|c|}
\hline Variable & Ideal Average & $\begin{array}{c}\text { Actual } \\
\text { Average }\end{array}$ & STD & Z & Remarks \\
\hline $\begin{array}{c}\text { Organizational Performance } \\
(\mathrm{Z})\end{array}$ & 6 & 7.20 & 1.230 & 4.875 & Significant \\
\hline
\end{tabular}

** Significant at the 0.05 of significance level $\left(\mathrm{Z}_{\text {tabel }}=1.645\right)$

Source: Data of Analysis Questionnaires, 2014

Table 8 shows the right side average test for the variables of organizational performance. The result was significant on the real level of $5 \%$ and the statistical hypothesis was rejected. This means that the organizational performance has been achieved well.

Based on the tables above, it can be explained that the results of the average test right side to the variable implementation of human resource management based on competency, implementation of knowledge management, organizational culture and organizational performance were significant at the $5 \%$ of significance level and the statistical null hypothesis was rejected. This means that the implementation of competency-based human resource management (CBHRM), implementation of knowledge management, organizational culture and organizational performance has been achieved well.

\subsection{Verification Analysis}

Based on the results of data processing using Smart PLS, the model structure can be described as Figure 1 below. 


\section{Macrothink}

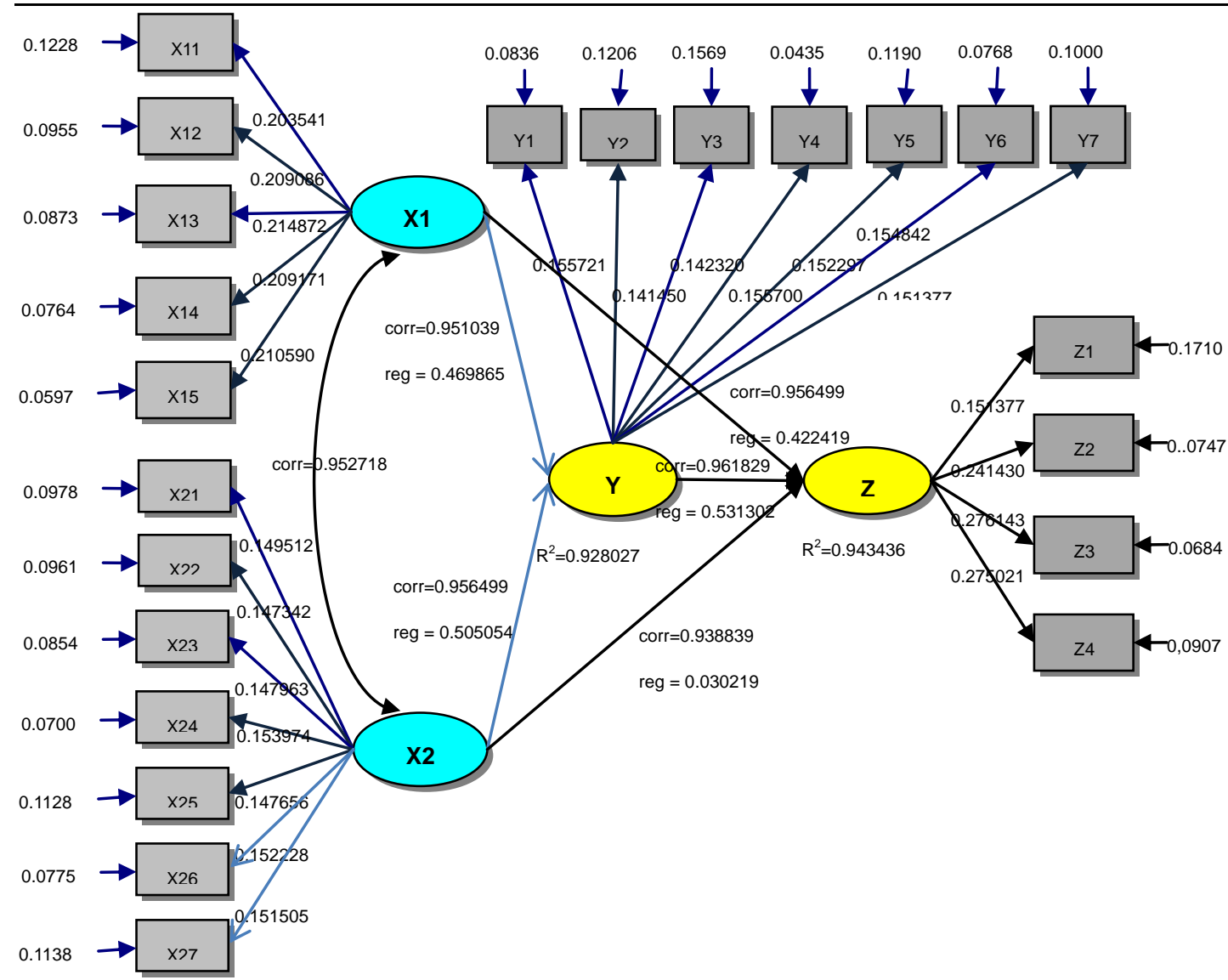

Figure 1

The implementation structure model competency-based human resource management and organizational performance against knowledge management through organizational culture Source: Results of Data Analysis Smart PLS

Equation model of organizational performance: `

1. $\mathrm{Y}=0.470 \mathrm{ICBHRM}+0.505 \mathrm{KM}+0.072$

2. $\mathrm{Z}=0.422419 \mathrm{ICHRM}+0.030219 \mathrm{KM}+0.531302 \mathrm{OC}+0.056564$.

The exogenous latent regression coefficient of variable implementation of competency-based human resource management $\left(\mathrm{X}_{1}\right)$, knowledge management $\left(\mathrm{X}_{2}\right)$ and organizational culture $(\mathrm{Y})$ against the endogenous latent variable of organizational performance $(\mathrm{Z})$ was positive. This meant that the variable implementation of competency-based human resource management $\left(\mathrm{X}_{1}\right)$, knowledge management $\left(\mathrm{X}_{2}\right)$ and organizational culture $(\mathrm{Y})$ could improve the organizational performance $(\mathrm{Z})$. The coefficients were the largest in improving the organizational performance. The organizational culture was the latent variable of 0.5313 unit.

\section{Conclusions}

1. The implementation of competency based human resource management, the implementation of knowledge management, the organizational culture and the organizational performance have been achieved well. 
2. The simultaneous implementation of measurements of competency-based human resource management and knowledge management had very large effect (92.80\%) of the organizational culture. Partial: (1) the implementation of competency-based human resource management had moderate influence (46.99\%) to the organizational culture; (2) the implementation of knowledge management influential moderate $(50.51 \%)$ to the organizational culture; and (3) the implementation of competency-based human resource management had a very high positive relationship (95.27\%) to the implementation of knowledge management.

3. The simultaneous implementation of competency-based human resource management and knowledge management had a small effect (20.37\%) on the performance of the organization. The hypothesis was accepted and it supported the theories. Partially: (1) the implementation of competency-based human resource management had a moderate effect (42.24\%) on the performance of the organization; (2) the implementation of knowledge management had a very small effect $(3.02 \%)$ on the performance of the organization, the hypothesis was rejected and it did not support the theories. The implementation of knowledge management could not directly improve the organizational performance.

4. The cultural organizations had a moderate effect $(53.13 \%)$ on the performance of the organization.

5. The simultaneous implementation of competency-based human resource management and knowledge management had a very large effect $(94.34 \%)$ on the performance of the organization through the organizational culture in the state-owned energy sector companies in Indonesia. Thus, the rest outside of the study variables was affected by the organizational performance as only $5.66 \%$.

\section{Suggestion}

Based on this conclusion, the implementation of competency-based human resource management and knowledge management would improve the performance of the organization if it was supported by a strong organizational culture climate.

\section{References}

Abell,A, and Oxbrow,N.2001. People Who make Knowledge Management Work: Knowledge Management Handbook Liebowitz, J, ed.Boca Raton, FL, CRC Press.

Alavi \& leidner.2001. Review : Knowledge Management, Knowledge Management System, Research Issues in Knowledge. Mis Quarterly, V.25.No.1 p.36-107.

Albers, James A.2009. A Practical Approach to Implementing Knowledge Management. Journal of Knowledge Management Practice.

Bassi, Laurie, Paul Harrison, Jens Ludwig, and Daniel McMurrer.1997. "The Impact of U.S. Firms' Investments in Human Capital on Stock Prices."

Bhatt, D.2001. The Knowledge Management Spectrum-Undestanding the Knowledge Management Landscape. Journal of Knowledge Management, 5(1) p.33-42.

Chong, Siong Choy and Choi Young Suk. 2005. Critical Factor in Successfull Implementation of Knowledge Management. Journal of Knowledge Management Practices. 
Enas Hamzi Mohammad Hijazeh. 2011. Adopting a Competency Based Human Resource Management System in Palestine Cellular Communication LTD JAWWAL.

Davenport, Thomas H., and Laurence Prusak. 1998. Working Knowledge: How Organizations Manage What They Know. Harvard Business School Press.

Dubois D.David, William J.Rothwell.2004. The Competency Toolkit, Vol.1. HRD Press, Us and Canada.

Dubois, David D \& William Rothwell.2004. Competency-Based Human Resource Management. Davies Black Publishing. California.

Frappaolo,C.'Wayne, Tom.1997. Knowledge Management : From Terra Incognitia to Terra Firma. Delphi Group.com.USA.

Horwitch, M. \& Armacost, R. 2002. Helping Knowledge Management Be All It Can Be. Journal of Business Strategy, pp.27-31.

Kandula R. Srinivas.2013. Competency Based Human Resource Management: A Complette Text With Case Studies on CompetencyMapping, Modelling, Assessing, and Applying. Gate Corporation. Bangalore, Delhi.

Kaplan.Robert and David P. Norton. 1996. The Strategy Focused Organization. Boston. Massachusetts. Harvard Business School Press.

Kaplan, Robert S Noorton, David P.2000. The Strategy Focused Organization, How Balanced Scorecard Company Thrive in the New Business Environment. Harvard Business Press Boston.

Kusno Prijono.2008. e-Indonesia Initiative.

Malhotra Yogesh, 1998, "Integrating Knowledge Management Technologies in Organizational Business Process: getting real time enterprises to deliver real business performance", Journal of Knowledge Management Vol. 9 No. 1, 2008 pp.7-28, Emerald Group Publishing Limited ISSN 1376-3270.

Mubarrak Sigit.2012. Benchmarking CBHRM di PT Telkom Indonesia.

Nonaka, Ikujiro; von Krogh, Georg . 2009.Tacit Knowledge and Knowledge Conversion: Controversy and Advancement in Organizational Knowledge Creation Theory".

Nonaka,I. \& Takeuchi,H.1995, The knowledge Creating company : How Japanese companies create the dynasties of innovation. Oxford.

Newman, Brian, 2009," The Knowledge Management Theory papers: A Series of Papers on the theories, processes and practice behind knowledge management A frame work for characterizing knowledge management methods, practices, and technologies. Washington University Course EMGT 298TI.

O’Dell, Carla. 2004. The Executive's Role on Knowledge Management. Houston: American Productivity and Quality Center.

Robbins, Stephen P.2010. Organization Theory, Structure Design and Aplication. United of America Seventh Edition. Prentice-Hall Int.Inc.

Schlussel.2002. How do You Measure the Knowledge Management (KM) Maturity of Your Organization? Matrics that Assets on Organization's. KM State USAWC.

Schoonover, Stephen C. 2002. Implementing Competencies A Best Practice Approach. Schoonover Associate Inc, 2002a. 
Simpson Suzanne, Mc Kay Lorraine. 2008. Competency Based Human Resource Management.

Stephen Josephant.2011. Fundamental of Human Resource Management: Emerging Experiences From Afric. African Studies Centre. African Public Administration and Management Series, vol.2.

Wong, K.Y.2005. Critical Success Factors for Implementing Knowledge Management in Small and Medium Enterprises. Industrial Management \& Data Systems, Vol.105, No.3 : 261-279.

Veithzal Rivai \& Ella Jauvani Sagala. 2009. Manajemen Sumber Daya Manusia untuk Perusahaan, dari Teori ke Praktek, edisi ke-2, Rajawali Pers. 